\title{
Editorial: genetics, information and identity
}

\author{
Sheelagh McGuinness • Bert-Jaap Koops • \\ Eva Asscher
}

Received: 27 September 2010 / Accepted: 4 October 2010 /Published online: 21 October 2010

(C) The Author(s) 2010. This article is published with open access at Springerlink.com

\section{Introduction}

IDIS is a multidisciplinary journal with a focus on identity in the information society. The information society is usually associated with information and communication technologies, such as computers, mobile phones and the Internet, and with information in the form of computer- or human-readable data. In this special issue on genetics, information and identity, however, we focus on a different type of information, namely genetic information. The DNA of the human genome is often called a 'blueprint' of human life, containing information that regulates - in various and very complex ways - most of the processes in human life. In this sense, genetics may well be considered an information technology in its own right.

Genetic information is becoming ever more important in society, although current knowledge of the human genome and how the genome relates to human life is still limited. Nevertheless, what knowledge we have about the genetic make-up of peoplewhether in terms of congenital diseases or medical conditions, or in terms of propensities to develop certain physical or behavioural characteristics - is increasingly being used, by data subjects or others, to make decisions that have more or less serious consequences. Examples can be found, inter alia, in the areas of reproductive technologies (pre-implantation genetic diagnosis and embryo selection, prenatal

\section{S. McGuinness}

Centre for Professional Ethics, Keele University, Room CBC 2.027, Chancellor's Building, Keele, Staffordshire ST5 5BG, UK

e-mail: s.mcguinness@peak.keele.ac.uk

\section{B.-J. Koops $(\bowtie)$}

Tilburg Institute for Law, Technology, and Society, Tilburg University, PO Box 90153, 5000 LE Tilburg, The Netherlands

e-mail: e.j.koops@uvt.nl

\section{E. Asscher}

Department of Medical Ethics and Philosophy of Medicine, ErasmusMC, PO Box 2040, 3000CA Rotterdam, The Netherlands

e-mail: e.asscher@erasmusmc.nl 
screening), genetic screening in health care and prevention (or lifestyle interventions), family life (paternity testing), insurance, employment and DNA forensics (DNA profiles, deriving physical characteristics and bio-ancestral information for identifying suspects).

Genetic information has close connections with two forms of identity, ipse and idem. ${ }^{1}$ It relates, first, to idem identity or numerical identity. Idem identity is the third-person attribution of sameness, usually in an objective perspective: this person is Jane Doe, the same as the person to whom this identity card she is showing was given. Numerical identity is related to continued existence over time and thus what makes a particular individual at one time the same individual at another time. It also appeals to something that is essentially one individual's continuous life. ${ }^{2}$ These concepts are relevant when genetic information is used for identification purposes, for example in DNA forensics or parenthood testing. Idem identity also surfaces in the bioethical topos of Derek Parfit's non-identity problem. This problem relates to the issue of how reproductive choices and interventions affect future generations; although, as Colin Gavaghan's paper highlights, we are inclined to say that, for example, pre-implantation genetic screening and selection affect the future child, Parfit argues that this is not the case, since without the intervention, this particular child would simply not have been born (rather, in her place, a different, numerically distinct, child would have been born). This non-identity problem has important consequences for moral reasoning about future generations. ${ }^{3}$

Even more significantly, genetic information relates, second, to ipse identity or narrative identity. Ipse identity refers to a first-person perspective on what constitutes oneself, in a subjective perspective: I am Jane Doe, feeling insecure because this police officer barking at me to show my identity card seems to think I am a criminal. Narrative identity is similar to ipse identity and can be described as the individual who is realistically described in one's life story, as told by oneself. ${ }^{4}$ These are key concepts when we consider how genetic information impacts upon identity construction. To name but a few examples, DNA tests for ethnic origin (a booming market in the USA), being (self-)diagnosed as having a certain genetic disease, discovering your parents selected you as an embryo because you could be a 'saviour sibling' for your sister, and the '\$1000 genome' allowing people to order their genetic 'blueprint' via the Internet all affect the way individuals perceive themselves, looking through the 'glasses' of their genome. The genetic information associated with these applications may influence people's sense of self in various ways, both positively and negatively. It may also have serious implications for how others perceive individuals, for example, as Ruth Wilkinson's paper describes regarding genetic discrimination and insurance applications.

\footnotetext{
${ }^{1}$ The concepts of idem and ipse identities were introduced by Paul Ricoeur, (1990/1994), Oneself as Another (K. Blamey, Trans.), Chicago: The University of Chicago Press. For a conceptual discussion of idem and ipse identity and their interrelationship, see M. Hildebrandt et al. (eds) (2008), D7.14a: Where Idem-Identity meets Ipse-Identity. Conceptual Explorations, FIDIS, http://www.fidis.net.

${ }^{2}$ See for instance DeGrazia D, Human Identity and Bioethics. Cambridge 2005, Chapter 2: 'Numerical Identity and Essence'.

${ }^{3}$ See Parfit (1984); Stephen Wilkinson, Choosing Tomorrow's Children. The Ethics of Selective Reproduction, Oxford: Oxford UP.

${ }^{4}$ See note 2, Chapter 3, 'Narrative Identity and Self-creation'; the individual's perspective on facts about him determine the narrative identity, thus different facts may stand out to the individual concerned (and thus are part of their narrative identity) than may be noticed by others.
} 
The relationship between genetic information and the two forms of identity has triggered us to produce a special issue in Identity in the Information Society on the interplay of genetics, information and identity.

\section{The papers in this special issue}

The special issue includes papers from a range of disciplines: law, ethics, genomics and science communication. These discuss and analyse different aspects of the interplay between genetic information and identity from various perspectives.

The first paper in the special issues is a guest essay by Colin Gavaghan. Gavaghan discusses the difficulty that lawyers face when trying to create laws which accurately reflect the nature of personal identity and the implications of this for concepts such as criminal responsibility. Gavaghan cautions against identity becoming a legal 'blind spot'. He moves on to describe the grip that genetic essentialism - the belief that we are in some ways defined by our genes - often has on our concept of self. Here the distinction between narrative and numerical identity becomes very important. Many hold essentialist accounts of numerical identity, that is, the belief that had a different sperm and egg been brought together than the ones which produced me then a numerically distinct individual would exist. Fewer hold essentialist accounts of narrative identity, that is to say, the view that I am the way I am solely because of my physical or genetic make-up. Most people believe that narrative identity is a much broader concept than pure numerical identity, incorporating the impact of environmental factors, socialisation and education, to name but a few things. Gavaghan moves on to discuss the pervasive way in which identity has now become a common theme in everyday speech, for example in fictional literature. In a similar vein to 'gene talk' described below, we also have 'identity talk'. A question that arises when reading Gavaghan's piece is to what extent the law can accommodate anything other than a physical essentialist account of identity. The difficulty posed to any criminal justice system in dealing with 'other person' scenarios as described in this essay would be incredibly difficult. Gavaghan's paper provides an interesting insight into these difficulties.

Adam Henschke provides a conceptual framework for discussing bio-information and identity in his contribution Did You Just Say What I Think You Said? Talking About Genes, Identity And Information. He distinguishes three concepts of the gene (instrumental, nominal and the postgenomic molecular), four concepts of identity (numeric - which resembles idem identity in our introduction - and character, group and essentialised-which can be linked to ipse identity), and three types of information (source, message and receiver). Equipped with this conceptual typology, Henschke shows how easily discussions about genes and identity can suffer from miscommunication, when discussants have different concepts in mind for the term they use. For example, research results can easily be misunderstood by the media or the public because values and assumptions from the researchers are 'lost in translation'. A statement that 'identity is in the genes' can be innocuous in one context, but through 'concept creep' become morally problematic in another context.

Next, Ruth Wilkinson discusses the role of genetic information in insurance policy, in a paper with the tell-tale title: Genetic Information: Important but not "Exceptional". 
She analyses how the insurance industry perceives genetic information and handles such information. She illustrates how various pieces of legislation have defined genetic information and moved from this to various prohibitions and exceptions. Wilkinson spends some time discussing how this exceptionalises genetic information over and above other sorts of information which can or ought to be equally relevant to insurance provision. One interesting fact of Wilkinson's analysis is that there now exist moratoriums on the use of genetic information for insurance purposes, something that Wilkinson herself seems to endorse. This seems however to fall into the trap of exceptionalising genetic information in way which is counter to the idea that genetic information is not special. Wilkinson's arguments address the danger that insurance companies cannot be trusted to deal with genetic information in an appropriate manner and until such a time as they will they should not be allowed use it.

The theme of the special appeal of genetic information is then taken up by Anders Nordgren, who analyses identity rhetorics on the Internet in his contribution: The rhetoric appeal to identity on websites of companies offering non-health-related DNA testing. Focusing on consumer websites offering DNA fingerprinting and, particularly, ancestry tests, he shows how websites employ rhetorical force in appeals to people's sense of self. Nordgren highlights the role that genetics can play in giving an opportunity for individuals to place themselves within broader community structures. He puts forward the interesting hypothesis that appeals 'to identity on the websites of some consumer genomics companies can be seen as a response to the search for identity in modern pluralistic societies in which people have become uncertain about who they are'. Such rhetoric is probably also clever marketing which targets those who have become enraptured by the concept of identity as described by Gavaghan above.

Ernesto Schwartz and Irma Silva-Zolezzi follow up the theme of genetic ancestry markers in relation to identity, not on an individual level but in terms of national identity. They discuss the role of the genome in Mexican nationalist imagery in "The Map of the Mexican's Genome": overlapping national identity, and population genomics. The idea that genetics and genes show who or what one really is, is the basis of popular notions of national identity and ethnicity and their genetic counterpart. Schwartz and Silva-Zolezzi describe the interesting phenomenon that a social, popular Mexican national identitarian narrative-Mestizaje - is able to influence the interpretation of population data. Thus the dominant notions of the popular Mestizaje identity are affecting the outcomes and conclusions from population genetics projects, such as the haplo-map project. The conclusions become shaped by the dominant identitarian narrative, rather than vice versa as would be expected.

\section{Common themes}

While the papers in this issue provide different perspectives on the subject of this special issue, certain key themes become evident in all submissions. For the purposes of this editorial we want to highlight three themes we find particularly 
salient: 'gene talk' and the rhetorical force of appealing to genetic information, genetic exceptionalism, and concepts of community and ethnicity.

This first theme which is evident in all the papers in this special issue has been described by Sarah Franklin as follows (Franklin 2006):

'Genes are powerful, and consequently they are political-indeed they are a classic example of what historian Michel Foucault terms "biopower," in that they are inextricably linked to the idea of management of the population (in terms of health, for example), while also being regarded as inherent qualities of the individual. Significantly, they are both highly technical and commonsensical-like atoms, they are invisible, yet few would deny that they exist or are, indeed, the essence of "real" life. Evelyn Fox Keller argues that the gene is one of the most powerful scientific concepts ever created (2000), and as feminist sociologist and historian Barbara Duden has argued, "gene talk" has become ubiquitous, as are its constitutive, repetitive, and cumulative effects on all of us who are interpellated by the very idea of having genes, being genetic, or embodying a genetic identity (Duden and Samerski 2003). This power of "genetic information" to enroll us in the certainty of itself is what Dorothy Nelkin and Susan Lindee famously named "the DNA mystique" (1995).'

The concept of 'gene talk' permeates all papers in this special issue and in Gavaghan's paper he describes a similar level of 'identity talk' which echoes Franklin's above quote. The force of appeals to genetics and genetic identity in how we conceptualise ourselves is evidenced in the many web-pages which Nordgren analyses in his paper. The frequent use of the word 'gene' in common everyday language is evidenced by both Henschke and Wilkinson. With this common usage the danger of misunderstanding and 'conceptual misconnection' increases. Henschke's paper outlines the various ways in which words are understood by different groups and the impact of context and background assumptions on the understandings that we have for words such as 'gene' and 'identity'. In Schwartz's and Silva-Zolezzi's contribution the differing interpretations of probabilistic genetic identities is shown in the context of national identities in Mexico. Genes and genetics are thus used to refer to a range of different phenomena and linked to different concepts of identity.

The second common theme is the role of 'genetic exceptionalism'. Genetic information is often privileged by individuals, governments, industry, as being more important than other seemingly relevantly similar information. Wilkinson suggests that discussion of the importance of genetic information and the esteem in which this information is held is akin to a religious fervour. Nordgren in his paper states that genes are perceived by some as having a quality similar to the soul. He highlights the deterministic and essentialist way in which genes and identity are linked by companies wishing to market direct to consumer DNA tests. Similarly, Henschke points out how some accounts essentialise character identity to a genetic cause, explaining someone's violence by his carrying a monoamine oxidase A (MAOA) genotype dubbed the 'warrior gene'. This goes to show the power of the gene in shaping the complete identity according to the imagination of some. It also shows how intrinsically linked with the essence of individuals and their ipse identity the 
gene is held to be. Although this may not be valid from a scientific point of viewafter all, what constitutes human beings is not only an extremely complex interplay of nature and nurture ${ }^{5}$, whereby nature is based on genetics but develops in interaction with itself and its environment (for instance, the womb) - but there is no denying the force in real life, through 'gene talk', of genetic determinism and genetic exceptionalism.

A third common theme is the role of genetics in identity and community-building. Although Wilkinson's paper does not deal explicitly with the concept of identity, insurance is pre-eminently a field in which questions of solidarity and categorisation surface, and consequent group boundaries are set. She describes well the impact which treatment of genetic information can have on individuals and their life plans, including the role of self-identification in the company's categorisation that you belong to a 'disease' category. This echoes points made by Nordgren about the important role which genetic information may play in our self-conception. It is interesting to note here that Schwartz and Silva-Zolezzi themselves, in their contribution, seem to agree with the view that genetic information is something special and can contribute information to who one is with regard to (ethnic) identity. Nordgren's paper links well with Schwartz's and Silva-Zolezzi's work in showing the role that genetics plays in conceptions of community and ethnicity. At the same time, Henschke warns against equating certain genotypes with character or group identity, since genetic correlations that may be innocuous in a research setting can turn foul when used in a racist manner in other contexts, for example when people start reducing the Maori population to the MAOA 'warrior gene'. The possible links between genetics and group identity form a double-edged sword, as they can empower as well as harm individuals and communities.

\section{Conclusion}

At the end of this editorial, we find ourselves caught in a conundrum. Although, as Wilkinson argues, genetic information is important but not special, and ought in that respect to be treated alongside other types of sensitive, revealing or identity-related information, there is no escaping the deeply ingrained notion that genes are special. This is evident from Wilkinson's own conclusion, where she argues that legislators and policy-makers must tackle genetic information and its associated problems head on. That conclusion would apply to many other types of information - for instance, location data, telecommunications data and computer-generated group profiles-but the fact that Wilkinson specifically targets genetic information in her paper, implies that she gives genetic information special attention and treatment herself. We cannot deny we are doing the same, as we zoom in on genetic information and identity in this special issue, based on the assumption that the combination of genetics, information and identity has its own peculiar fascinations and challenges.

However, we do not think it wrong to zoom in on genetics as a special issue. On the contrary: genetic information is fascinating and merits our full attention, not the least through its multifold interplay with numerical and narrative identity. Richard

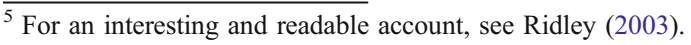


Dawkins has coined the word 'meme' as 'a monosyllable that sounds a bit like "gene", to indicate the idea of a unit of cultural transmission from mind to mind, much in the way that genes are a unit of biological transmission from genome to genome Dawkins (1976/1989). It is somewhat ironic that the idea of the gene, not least through the forcible style and rhetorical appeal of Dawkin's work and his metaphor of the 'selfish gene', has become such a powerful meme itself.

Genetic information triggers hopes and fears, quests and quagmires in our individual and collective searches for identity. For all the rhetoric and misconceptions involved in how websites, insurance companies, legislators and the public may perceive and handle genetic information in the construction of human identity, there remains, somewhere, a core truth in the idea that genes and language describing it are special for our identity. That, whether we like it or not, is the power of imagination, narrative and fiction (cf Mooij (1993); Gibson (2007)).

Open Access This article is distributed under the terms of the Creative Commons Attribution Noncommercial License which permits any noncommercial use, distribution, and reproduction in any medium, provided the original author(s) and source are credited.

\section{References}

Dawkins R. The Selfish Gene, 2nd edn. Oxford, Oxford UP; 1976/1989. p. 192.

Franklin S. Born and made: an ethnography of preimplantation genetic diagnosis. Princeton: Princeton University Press; 2006.

Gibson J. Fiction and the weave of life. Oxford: Oxford University Press; 2007.

Mooij JJA. Fictional realities. The uses of literary imagination. Amsterdam: John Benjamins; 1993.

Parfit D. Reasons and Persons. Oxford: Clarendon; 1984. p. 351-79.

Ridley M. Nature via nurture: genes, experience, and what makes us human. New York: Harper Collins. 2003 